\title{
Adaptation of Muscle to Exercise
}

\author{
INCREASE IN LEVELS OF PALMITYL CoA SYNTHETASE, \\ CARNITINE PALMITYLTRANSFERASE, AND PALMITYL CoA \\ DEHYDROGENASE, AND IN THE CAPACITY TO OXIDIZE
} FATTY ACIDS

\author{
P. A. Molé, L. B. Oscar, and J. O. Holloszy \\ From the Department of Preventive Medicine,Washington University School \\ of Medicine, St. Louis, Missouri 63110
}

A B S T R A C T The capacity of gastrocnemius and quadriceps muscles to oxidize palmitate, oleate, linoleate, palmityl CoA, and palmityl carnitine doubled in rats subjected to a program of treadmill running. The rate of palmitate oxdation by whole homogenates of, or the mitochondrial fraction from, leg muscles was twice as great per gram wet weight of muscle in the trained as in the sedentary animals over a wide range (0.125-1.5 $\mathrm{mM}$ ) of palmitate concentrations.

The levels of activity of carnitine palmityltransferase, palmityl CoA dehydrogenase, and mitochondrial ATPdependent palmityl CoA synthetase expressed per gram of muscle doubled in gastrocnemius and quadriceps muscles in response to the running program. The protein content of the mitochondrial fraction from these muscles was increased approximately $60 \%$.

\section{INTRODUCTION}

Long-chain fatty acids can serve as the major energy source for skeletal muscle metabolism during prolonged exercise (1-5). The relative amounts of fat and of carbohydratae utilized during a bout of exercise depend in part on the individual's level of physical training. Men and animals that have adapted to regularly performed endurance exercise, such as long-distance running, derive more of their energy from fatty acid oxidation and

\footnotetext{
Doctors Molé and Oscai were Postdoctoral Research Fellows supported by U. S. Public Health Service Training Grant AMO5341. Dr. Holloszy is the recipient of U. S. Public Health Service Research Career Development Award K4-HD-19,573.

Received for publication 18 March 1971 and in revised form 23 May 1971.
}

less from carbohydrate catabolism than do their untrained counterparts during exercise of submaximal intensity $(1,6-8)$. This difference viewed in the context of studies demonstrating that muscle mitochondria can undergo major adaptive changes in response to exercise (9-12) suggested the possibility that physical training might induce an increase in the capacity of skeletal muscle to oxidize fatty acids. Evidence that such an adaptation does occur was obtained in a preliminary study (13) in which it was found that homogenates of leg muscles from chronically exercised rats released ${ }^{14} \mathrm{CO}_{2}$ from palmitate $-1{ }^{14} \mathrm{C}$ at a significantly increased rate. This observation was confirmed in the present detailed study in which it was further found that the levels of activity per gram wet weight of muscle of carnitine palmityltransferase (palmityl CoA-carnitine palmityltransferase, EC 2.3.1.-), palmityl CoA dehydrogenase (fatty acyl CoA : FAD oxidoreductase, EC 1.3.2.2) and mitochondrial ATP-dependent palmityl CoA synthetase (palmitic acid: CoA ligase [AMP], EC 6.2.1.3) doubled in leg muscles of rats subjected to a program of running. The capacity of gastrocnemius and quadriceps muscles to oxidize oleate, linoleate, palmityl CoA, and palmityl carnitine also increased twofold in response to the exercise.

\section{METHODS}

Animal care and exercise program. Male rats of a Wistar strain (specific pathogen-free CFN rats) weighing 100 $g$ were obtained from Carworth Laboratory Animals, New City, N. Y., kept in individual cages, and fed Purina chow and water. They were divided into an exercising and two sedentary groups. The exercising animals were trained by means of a program of treadmill running as previously 
described $(9,10)$. After $12 \mathrm{wk}$, the exercisers were running continuously for $2 \mathrm{hr}$ day, 5 days/wk, up an $8^{\circ}$ incline at $31 \mathrm{~m} / \mathrm{min}$, with twelve $1 \mathrm{~min}$ intervals of running at $42 \mathrm{~m} / \mathrm{min}$ interspersed through the work period. They were maintained at this work level until they were sacrificed. This exercise program has been found to result in a large increase in capacity for prolonged running and does not result in muscle hypertrophy $(9,14)$.

Sedentary control rats were divided into a paired weight group in which food intake was adjusted so as to maintain their body weights the same as those of the exercising animals, and a freely eating group which was provided with food ad lib. These animals were not subjected to treadmill running.

Tissue preparation. Animals were killed approximately $66 \mathrm{hr}$ after their last exercise session. They were anesthetized with ether, decapitated, and thoroughly exsanguinated. Gastrocnemius and quadriceps muscles were dissected out and chopped into a fine mince which was thoroughly mixed. A portion of the mixed muscle mince was homogenized in $0.175 \mathrm{M} \mathrm{KCl}$, containing $0.1 \mathrm{~mm}$ EDTA, using a glass Potter-Elvehjem homogenizer immersed in ice water. After gross breaking up of the muscle, homogenization was completed with two complete passes of the tube. The homogenate contained $1 \mathrm{~g}$ of muscle per $10 \mathrm{ml}$. The remainder of the muscle mince was used for measurement of cytochrome c concentration.

Mitochondria were prepared by first centrifuging a portion of the homogenate for $15 \mathrm{~min}$ at $700 \mathrm{~g}$; the $700 \mathrm{~g}$ supernatant fluid was decanted and centrifuged again at $700 \mathrm{~g}$ for $15 \mathrm{~min}$. The second $700 \mathrm{~g}$ supernatant fluid was then centrifuged for $15 \mathrm{~min}$ at $8000 \mathrm{~g}$. The resulting mitochondrial pellet was suspended in $250 \mathrm{~mm}$ sucrose, containing $2 m \mathrm{M}$ EDTA, $\mathrm{pH} 7.4$.

Reagents. Palmitic-1-14 $\mathrm{C}$ acid, oleic- $1-{ }^{14} \mathrm{C}$ acid, uniformly labeled palmitic- ${ }^{14} \mathrm{C}$ acid, and palmityl-1-14 $\mathrm{C}-\mathrm{CoA}$ were obtained from New England Nuclear Corp., Boston, Mass.

Bovine serum albumin, Fraction V, "essentially fatty acidfree," was obtained from Sigma Chemical Co., St. Louis, Mo., and extracted according to the method of Goodman (15) to further decrease fatty acid content. This preparation is subsequently referred to as "fatty acid-free" albumin. The molecular weight of albumin was taken to be 66,000 (16).

CoA, cytochrome c (type II), hexokinase, ADP, ATP, and palmitic acid were obtained from Sigma Chemical Co. L-Carnitine, palmityl CoA, and oleic acid were purchased from Nutritional Biochemicals Corporation, Cleveland, Ohio.

L-Palmityl carnitine was a generous gift from Dr. Rubin Bressler, Duke University Medical Center.

The fatty acids were dissolved in ethanol (17). After addition of the alcoholic solutions of the free fatty acids, the final concentration of ethanol was $1 \%$ in the reaction media used for studies of fatty acid oxidation (17).

Assay methods. Mitochondrial $\mathrm{O}_{2}$ uptake was measured in a Gilson differential respirometer (Gilson Medical Electronics, Inc., Middleton, Wis.) at $30^{\circ} \mathrm{C}$ with air as the gas phase. In those experiments in which $\mathrm{P}: \mathrm{O}$ ratios were not determined, each flask contained, in a final volume of 2 $\mathrm{ml}: 5 \mathrm{~mm} \mathrm{MgCl}_{2}, 20 \mathrm{~mm} \mathrm{KCl}, 125 \mathrm{~mm}$ sucrose, $30 \mathrm{~mm}$ potassium phosphate buffer, $2 \mathrm{~mm}$ EDTA, $10 \mathrm{~mm}$ Tris- $\mathrm{HCl}, 1$ $\mathrm{mM} \mathrm{Na}$ malate, $0.15 \mathrm{~mm}$ fatty acid-free albumin, $0.078 \mathrm{~mm}$ cytochrome c, $10 \mathrm{~mm}$ ADP, $1 \mathrm{mM}$ ATP, and mitochondria from $\frac{1}{3}$ or $\frac{1}{2} \mathrm{~g}$ of muscle. The concentrations of substrate and of $\mathrm{CoA}$ and L-carnitine (when present), are indicated for each experiment. The $\mathrm{pH}$ of the mixture was 7.2. After $10 \mathrm{~min}$ of thermoequilibration, $\mathrm{O}_{2}$ uptake was measured for a $10 \mathrm{~min}$ period; the ADP was then tipped in from the side arm, and $\mathrm{O}_{2}$ uptake was measured for two more 10min periods.

For determination of $\mathrm{P}: \mathrm{O}$ ratios during the oxidation of palmityl CoA or palmityl carnitine, the reaction medium contained, in a final volume of $2 \mathrm{ml}: 5 \mathrm{~mm} \mathrm{MgCl}_{2}, 20 \mathrm{~mm}$ $\mathrm{KCl}, 100 \mathrm{~mm}$ sucrose, $25 \mathrm{~mm}$ glucose, $30 \mathrm{~mm}$ potassium phosphate buffer, $2 \mathrm{~mm}$ EDTA, $10 \mathrm{~mm}$ Tris-HCl, $1 \mathrm{~mm}$ $\mathrm{Na}$ malate, $0.15 \mathrm{~mm}$ fatty acid-free albumin, $0.078 \mathrm{~mm}$ cytochrome c, $2.5 \mathrm{~mm}$ ATP, $2 \mathrm{mg}$ of hexokinase, and either $0.3 \mathrm{~mm}$ palmityl $\mathrm{CoA}$ and $1 \mathrm{~mm}$ carnitine, or $0.3 \mathrm{~mm}$ palmityl carnitine and $0.025 \mathrm{~mm} C o A$. The $\mathrm{pH}$ of the mixture was 7.2. After $10 \mathrm{~min}$ of thermoequilibration, $\mathrm{O}_{2}$ uptake was measured for $10 \mathrm{~min}$ in the absence of phosphate acceptor. The ATP, glucose, and hexokinase were then tipped in from the side arm, and $\mathrm{O}_{2}$ consumption and $\mathrm{P}_{1}$ disappearance during the following $20 \mathrm{~min}$ period were measured (9).

The capacity of whole homogenates of muscle to oxidize ${ }^{14} \mathrm{C}$-labeled fatty acids was assessed by measuring the rate of ${ }^{14} \mathrm{CO}_{2}$ production. The reaction mixture contained, in a final volume of $2 \mathrm{ml}$ : $5 \mathrm{~mm} \mathrm{MgCl}_{2}, 87.5 \mathrm{~mm} \mathrm{KCl}, 40 \mathrm{~mm}$ potassium phosphate buffer, $2 \mathrm{~mm}$ EDTA, $2 \mathrm{~mm}$ ADP, 10 mM Tris- $\mathrm{Cl}, 0.078 \mathrm{~mm}$ cytochrome c, $0.15 \mathrm{mM}$ fatty acidfree albumin, and homogenate equivalent to $100 \mathrm{mg}$ of muscle. The concentrations of ${ }^{14} \mathrm{C}$-labeled substrate and of $\mathrm{CoA}$ and carnitine are indicated for each experiment. Reaction mixtures were placed in $25-\mathrm{ml}$ flasks fitted with serum caps and hanging center wells, in a shaking Dubnoff incubator at $30^{\circ} \mathrm{C}$. The ${ }^{14} \mathrm{CO}_{2}$ produced was trapped in $0.4 \mathrm{ml}$ of Hyamine hydroxide, placed in the center well, as described by Jones and Blecher (18). Radioactive Hyamine carbonates were transferred to vials containing $5 \mathrm{ml}$ of Insta-Gel (Packard Instrument Co., Inc., Downers Grove, Ill.) scintillator fluid for determination of radioactivity in a Philips liquid scintillation counter. Efficiency was monitored by the external standard channel ratio method with ${ }^{133} \mathrm{Ba}$ as the external source of radiation.

Mitochondrial suspensions were frozen and thawed three times, followed by vigorous homogenization before measurement of enzymatic activity. Assays were conducted at $30^{\circ} \mathrm{C}$.

ATP-linked palmityl CoA synthetase activity was measured as described by Pande and Mead (19) using the hydroxamate trapping method of Kornberg and Pricer (20). Concentrations of substrates in the reaction mixture were $4 \mathrm{~mm}$ palmitate and $1.2 \mathrm{~mm}$ CoA.

Palmityl CoA-carnitine palmityltransferase activity was determined by measuring the palmityl $\mathrm{CoA}$ formed from L-palmityl carnitine and CoA (cf. reference 21 ). The reaction mixture (cf reference 22 ) contained, in a final volume of $1 \mathrm{ml}$ : $500 \mathrm{~mm}$ hydroxylamine, $\mathrm{pH} 7.4 ; 0.6 \mathrm{~mm}$ CoA; $5 \mathrm{~mm}$ glutathione; $0.6 \mathrm{~mm}$ palmityl carnitine; and $75 \mathrm{~mm}$ Tris- $\mathrm{Cl}, \mathrm{pH}$ 7.4. A control lacking $\mathrm{CoA}$ was included for each experimental sample. After a $5 \mathrm{~min}$ period of thermoequilibration, the reaction was started by addition of enzyme. After $30 \mathrm{~min}$ of incubation with shaking, the reaction was terminated by the addition of $2 \mathrm{ml}$ of $6 \%$ perchloric acid. The tubes were centrifuged, and the supernatant fluid was decanted. The residue was extracted with $3 \mathrm{ml}$ of reagent $\mathrm{A}$ of Hill that had been freshly diluted $1: 10$ in absolute ethanol (23). The absorbance of the ironpalmitylhydroxamate complex was measured at $520 \mathrm{~m} \mu$ in a Gilford model 240 spectrophotometer. 
Palmityl CoA dehydrogenase activity was measured by following the rate of 2,6-dichlorophenolindophenol reduction at $600 \mathrm{~m} \mu$ (cf. reference 24). Assays were performed in a Gilford model 240 spectrophotometer, in $1 \mathrm{ml}$ cuvettes of $1 \mathrm{~cm}$ light path. Phenazine methosulfate (PMS) was used as the intermediate electron carrier. Reaction rates were measured at several different PMS levels. Results were extrapolatd to infinite $\mathrm{PMS}$ concentration $\left(\mathrm{V}_{\max }\right.$, PMS) by plotting the reciprocal of the velocities against the reciprocal of PMS concentrations. The reaction mixture contained $100 \mathrm{~mm}$ potassium phosphate buffer, $\mathrm{pH} 7.0$; $0.034 \mathrm{~mm}$ 2,6-dichlorophenolindophenol; $0.12 \mathrm{~mm}$ FAD; $0.2 \mathrm{~mm}$ palmityl $\mathrm{CoA}$; and $0.26 \mathrm{~mm}, 0.33 \mathrm{~mm}, 0.65 \mathrm{~mm}$, or $1.3 \mathrm{~mm}$ PMS. After a variable period, when change in absorbance due to oxidation of endogenous substrates in the mitochondrial preparations had stopped, the reaction was started by addition of palmityl CoA.

The concentration of cytochrome $\mathrm{c}$ in muscle was determined by the method of Williams and Thorp (25). Protein was determined by the biuret method (26). Homogenates and mitochondria were prepared for protein measurement by the procedure of Cleland and Slater (27).

\section{RESULTS}

L-Carnitine and $\operatorname{CoA}$ requirements for oxidation of long-chain fatty acids by homogenates and mitochondria of skeletal muscle. L-Carnitine and CoA were necessary cofactors for the oxidation of palmitic and oleic acids by skeletal muscle mitochondria. The mitochondrial fraction from $1 \mathrm{~g}$ of muscle consumed approximately 50 $\mu \mathrm{l}$ of $\mathrm{O}_{2}$ per $\mathrm{hr}$ when incubated in the absence of any substrate other than malate. Addition of $0.75 \mathrm{~mm}$ palmitate to the medium without L-carnitine or CoA did not result in an increase in $\mathrm{O}_{2}$ consumption above the values seen with malate alone. The presence of either CoA or L-carnitine alone resulted in a negligible increase in palmitate oxidation (Table I). However, when L-carnitine and CoA were both added in what appeared to be optimal concentrations, mitochondrial $\mathrm{O}_{2}$ uptake with palmitate as substrate increased approximately 10-fold (Table I). A similar response was seen with oleic acid as substrate.

In contrast to the response of the mitochondrial preparation, the rate of palmitate $-1{ }^{14} \mathrm{C}$ oxidation by whole homogenates of muscle increased approximately two- to threefold on addition of either CoA or carnitine alone (Table I). A possible explanation for this difference in response may be that whole homogenates have higher endogenous levels of these cofactors than does the mitochondrial fraction. Addition of both cofactors together in optimal concentrations resulted in an approximately sevenfold increase in the rate of oxidation of palmitic- $1-{ }^{14} \mathrm{C}$ acid. A similar response was seen when oleic $-1-{ }^{14} \mathrm{C}$ acid was used as substrate.

The concentrations of these cofactors that resulted in the highest rates of fatty acid oxidation with palmitic (or oleic) acid as substrate were $0.025 \mathrm{~mm}$ for CoA, and above $0.5 \mathrm{~mm}$ for L-carnitine (Table I). Higher con-
TABLE I

Effects of $\mathrm{CoA}$ and of L-Carnitine on Palmitic Acid Oxidation

\begin{tabular}{cccc}
\hline $\begin{array}{c}\text { CoA } \\
\text { concentration }\end{array}$ & $\begin{array}{c}\text { L-Carnitine } \\
\text { concentration }\end{array}$ & $\begin{array}{c}\text { Mitochondrial } \\
\mathrm{O}_{2} \text { uptake }\end{array}$ & $\begin{array}{c}\text { Homogenate }{ }^{14} \mathrm{CO}_{2} \\
\text { production }\end{array}$ \\
\hline$\mu M$ & $m M$ & $\mu l \mathrm{O}_{2} / h r$ per $\mathrm{g}^{*}$ & $\begin{array}{c}\text { dpm/min per } g \ddagger \\
0\end{array}$ \\
25 & 0 & 52 & 1134 \\
0 & 0 & 69 & 3483 \\
5 & 1.0 & 64 & 2597 \\
10 & 1.0 & 390 & - \\
25 & 1.0 & 483 & 6544 \\
50 & 1.0 & 543 & 7966 \\
100 & 1.0 & 424 & 6535 \\
25 & 1.0 & 377 & 6687 \\
25 & 0.1 & 367 & 6621 \\
25 & 0.25 & 475 & 7002 \\
25 & 0.5 & 535 & 8011 \\
\hline
\end{tabular}

The concentration of palmitic acid was $0.75 \mathrm{~mm}$. In experiments involving measurement of ${ }^{14} \mathrm{CO}_{2}$ production the palmitic acid contained $300,000 \mathrm{dpm}$ of palmitic-1 ${ }^{14} \mathrm{C}$ acid per $\mu$ mole. Values are averages for two representative experiments.

* $\mathrm{O}_{2}$ uptake is expressed as microliters of $\mathrm{O}_{2}$ utilized per hour by the mitochondrial fraction from $1 \mathrm{~g}$ of muscle.

$\ddagger^{14} \mathrm{CO}_{2}$ production is expressed as disintegrations per minute released per minute by homogenate of $1 \mathrm{~g}$ of muscle.

centrations of CoA had a slight inhibitory effect (Table I).

Oxidation of palmitate, oleate, linoleate, palmityl CoA, and palmityl carnitine by the mitochondrial fraction of muscle. The paired weight sedentary and the freely eating sedentary animals were not significantly different in any of the biochemical variables measured in the present study. Therefore, the results obtained on these two groups have been combined and are referred to jointly under the headings Sedentary Group or Sedentary Controls.

The mitochondrial fraction of (combined) gastrocnemius and quadriceps muscles from the exercised animals utilized approximately twice as much $\mathrm{O}_{2}$ as that of the sedentary group under conditions of uncontrolled respiration with palmitate as substrate (Table II, Fig. 1). This difference in the capacity to oxidize palmitic acid was demonstrable over a wide physiologic range of concentrations (Fig. 1). As shown in Table II, the rate of $\mathrm{O}_{2}$ consumption by the mitochondrial fraction from muscle of the runners was also approximately double that of the sedentary controls with oleic and linoleic acids, palmityl CoA, or palmityl carnitine as substrate. It is of interest that with the incubation medium used in these studies (containing CoA, L-carnitine, ADP, ATP, malate, albumin, and EDTA), the rates of $\mathrm{O}_{2}$ uptake with palmitic, oleic, or linoleic acids as substrate were similar to those seen with palmityl carnitine (Table II). Respiratory rates in both the exercised and sedentary groups were lower with palmityl CoA than with the other substrates. The concentration of palmityl $\mathrm{CoA}$ that gave the highest rate of $\mathrm{O}_{2}$ consumption was 
TABLE II

Oxidation of Palmitate, Oleate, Linoleate, Palmityl CoA, and Palmityl Carnitine by Mitochondrial Fraction of Muscles from Exercised and Sedentary Rats

\begin{tabular}{lccccc}
\hline & \multicolumn{5}{c}{ O2 consumption } \\
\cline { 2 - 6 } Group & Palmitate & Oleate & Linoleate & $\begin{array}{c}\text { Palmityl } \\
\text { CoA }\end{array}$ & $\begin{array}{c}\text { Palmityl } \\
\text { carnitine }\end{array}$ \\
\hline \multirow{2}{*}{ Runners } & & & $\mu l O_{2} / \mathrm{hr}$ per $g$ \\
Sedentary & $1069 \pm 37^{*}$ & $1084 \pm 50^{*}$ & $962 \pm 60^{*}$ & $776 \pm 42^{*}$ & $1120 \pm 55^{*}$ \\
& $(12)$ & $(5)$ & $(3)$ & $(5)$ & $(8)$ \\
& $509 \pm 22$ & $498 \pm 20$ & $523 \pm 36$ & $440 \pm 39$ & $516 \pm 25$ \\
& $(14)$ & $(8)$ & $(5)$ & $(8)$ & $(12)$ \\
\hline
\end{tabular}

Substrate concentrations were $0.75 \mathrm{~mm}$ for palmitic, linoleic, and oleic acids, and $0.3 \mathrm{~mm}$ for palmityl CoA and palmityl carnitine. Cofactor concentrations were $0.025 \mathrm{~mm}$ for CoA and $1 \mathrm{~mm}$ for L-carnitine. Carnitine was omitted from the flasks containing palmityl carnitine. The flasks contained mitochondria from either $\frac{1}{3} \mathrm{~g}$ (runners) or $\frac{1}{2} \mathrm{~g}$ (sedentary) of muscle, to give approximately $1.8-2 \mathrm{mg}$ of mitochondrial protein per flask. Values are means \pm SEM. The number of animals per group is given in parentheses. $\mathrm{O}_{2}$ uptake is expressed as microliters of $\mathrm{O}_{2}$ utilized per hour by the mitochondrial fraction from $1 \mathrm{~g}$ of fresh muscle.

* Runners vs. sedentary, $P<0.001$.

$0.3 \mathrm{~mm}$; higher levels resulted in a reduction of respiratory rate.

Respiratory control indexes and $\mathrm{P}: \mathrm{O}$ ratios with palmityl CoA or palmityl carnitine as substrates were not significantly different in the mitochondrial fractions from muscle of the exercised and sedentary animals.

The average $\mathrm{P}: \mathrm{O}$ ratio was $2.4 \pm 0.4$ with palmityl $\mathrm{CoA}$ and $2.4 \pm 0.4$ with palmityl carnitine for six run-

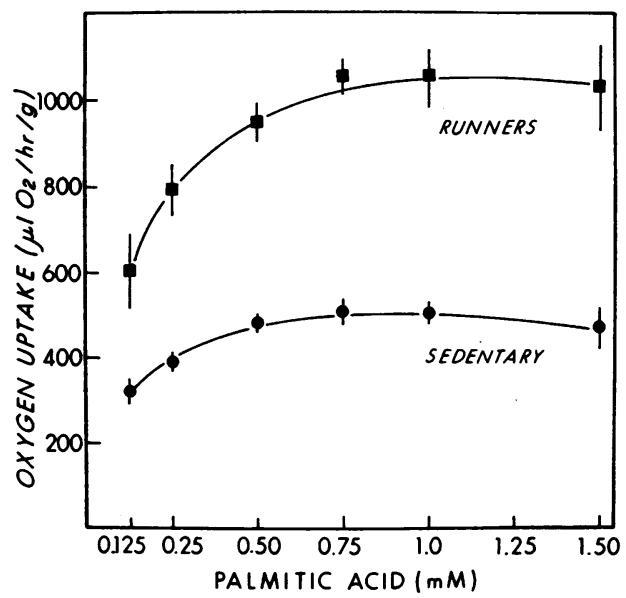

FIGURE 1 Relationship between palmitic acid concentration and rate of $\mathrm{O}_{2}$ utilization by the mitochondrial fraction from muscles of exercised and sedentary animals. The reaction mixture and the methods used are described under Experimental Procedure. Each flask contained $1 \mathrm{~mm} \mathrm{~L}-$ carnitine and $0.025 \mathrm{~mm}$ CoA. Each point is the mean for four to six animals. The vertical bars represent twice the SE. $\mathrm{O}_{2}$ uptake is expressed as microliters of $\mathrm{O}_{2}$ utilized per hour by the mitochondrial fraction from $1 \mathrm{~g}$ of fresh muscle. ners compared with $2.3 \pm 0.2$ with palmityl $\mathrm{CoA}$, and $2.4 \pm 0.3$ with palmityl carnitine for eight sedentary controls. The respiratory control index averaged 6.4 \pm 0.7 with palmityl $\mathrm{CoA}$ and $6.1 \pm 0.5$ with palmityl carnitine in the exercisers and $6.2 \pm 1.2$, and $6.8 \pm 1.1$ for the sedentary controls.

The protein content of the mitochondrial fraction from gastrocnemius and quadriceps was increased approximately $60 \%$ in the exercised animals. The average mitochondrial protein concentrations was $6.0 \pm 0.2 \mathrm{mg} / \mathrm{g}$ of fresh muscle for 12 runners, compared with $3.7 \pm 0.1$ $\mathrm{mg} / \mathrm{g}$ for 14 sedentary controls $(P<0.001)$. As a result, the increase in the capacity of the exercised animals' leg muscles to oxidize fatty acids is partly obscured when $\mathrm{O}_{2}$ consumption is expressed per milligram of mitochondrial protein. For example, $\mathrm{O}_{2}$ consumption with palmitate as substrate was $182 \pm 13 \mu 1$ of $\mathrm{O}_{2} / \mathrm{hr}$ per $\mathrm{mg}$ of mitochondrial protein for 12 runners, compared with $140 \pm 8 \mu 1 / \mathrm{hr}$ per $\mathrm{mg}$ for 14 sedentary controls. This difference is still statistically significant $(P<0.01)$.

Oxidation of palmitate $-1{ }^{14} \mathrm{C}$, palmitate $-U{ }^{14} \mathrm{C}$, oleate$1-{ }^{14} \mathrm{C}$, and palmityl-1- ${ }^{14} \mathrm{C}$ CoA by whole muscle homogenates. The rate of ${ }^{14} \mathrm{CO}_{2}$ production by whole homogenates of muscle, under conditions of uncontrolled respiration with palmitic- $1-{ }^{14} \mathrm{C}$ acid as substrate, was significantly greater in the exercised than in the sedentary group (Table III). This difference in the rate of palmitate oxidation by homogenates of muscle from the trained and sedentary animals was demonstrable over a wide physiologic range of palmitate concentrations (0.125$1.5 \mathrm{~mm}$ ). The capacity of muscle homogenates to oxidize palmitic-U- ${ }^{14} \mathrm{C}$ acid, oleic $-1-{ }^{14} \mathrm{C}$ acid, and palmityl-1 $1{ }^{14} \mathrm{C}$ $\mathrm{CoA}$ was also examined in a small number of exercised 
TABLE III

Oxidation of Palmitate-1-14 $C$, Palmitate- $U-{ }^{14} C$, Oleate- $1-{ }^{14} C$, and Palmityl-1-14 $C$ CoA by Homogenates of Muscles from Exercised and Sedentary Animals

\begin{tabular}{lcccc}
\hline \multirow{4}{*}{ Group } & \multicolumn{4}{c}{${ }^{14} \mathrm{CO}_{2}$ released } \\
\cline { 2 - 5 } Runners & Palmitate-1-14C & Palmitate-U-14C & Oleate-1-14C & Palmityl-1-14C CoA \\
\cline { 2 - 5 } & $16161 \pm 1270^{*}$ & $18708 \pm 1180^{*}$ & $18617 \pm 1845^{*}$ & $14506 \pm 3280 \ddagger$ \\
Sedentary & $(10)$ & $(3)$ & $(3)$ & $(3)$ \\
& $8905 \pm 130$ & $8897 \pm 720$ & $9547 \pm 816$ & $5220 \pm 1750$ \\
& $(14)$ & $(3)$ & $(3)$ & $(3)$ \\
\hline
\end{tabular}

The concentration of palmitate-1-14 $\mathrm{C}$, palmitate-U- ${ }^{14} \mathrm{C}$, and oleate-1-14 $\mathrm{C}$ was $0.75 \mathrm{~mm}$, while that of palmityl-1-14 $\mathrm{C} \mathrm{CoA}$ was $0.3 \mathrm{~mm}$. Each substrate contained approximately $300,000 \mathrm{dpm}$ of ${ }^{14} \mathrm{C}$ per $\mu$ mole. The reaction medium contained $1 \mathrm{~mm}$ L-carnitine and $0.025 \mathrm{~mm} \mathrm{CoA}$. Values are means \pm SEM. The number of animals per group is given in parentheses. ${ }^{14} \mathrm{CO}_{2}$ production is expressed as disintegrations per minute of ${ }^{14} \mathrm{CO}_{2}$ formed per minute by homogenates of $1 \mathrm{~g}$ of muscle.

* Runners vs. sedentary, $P<0.01$.

$\ddagger P<0.02$.

and sedentary animals. As shown in Table III, the running program resulted in a similar approximately twofold, increase in the capacity of gastrocnemius and quadriceps muscles to oxidize these substrates. The similar rates of oxidation of palmitate- $1-{ }^{14} \mathrm{C}$ and of palmitate- $\mathrm{U}_{-}{ }^{14} \mathrm{C}$ provide evidence that once $\beta$-oxidation of palmityl CoA was initiated, it went to completion.

ATP-dependent palmityl CoA synthetase, carnitine palmityltransferase, and palmityl CoA dehydrogenase activities. The levels of activity of these three enzymes involved in the activation, transport, and catabolism of long-chain fatty acids were measured in the mitochondrial fraction of gastrocnemius and quadriceps muscles. As shown in Table IV, the values obtained for all three enzymes were approximately twice as high in the exercised as in the sedentary group. Enzymatic activity is expressed per gram wet weight of muscle as this seems the most useful reference when relating enzyme content to functional capacity. As mentioned above, the protein content of the mitochondrial fraction was approximately $60 \%$ higher in the exercised groups. As a result, the adaptive increase in the levels of activity of these enzymes is largely obscured when activity is expressed per milligram of mitochondrial protein.

The magnitude of the increase in the levels of activity of these enzymes was similar to that of the concentration of cytochrome $c$, which was used as a marker for the respiratory chain. The concentration of cytochrome $\mathrm{c}$ in (combined) gastrocnemius and quadriceps muscles was $18.7 \pm 0.5 \mathrm{nmoles} / \mathrm{g}$ of muscle for $14 \mathrm{run}$ ners, compared with $9.4 \pm 0.5$ nmoles $/ g$ for 14 sedentary animals $(P<0.001)$.

\section{DISCUSSION}

Earlier reports that palmitate is oxidized more slowly by mitochondria from heart $(28,29)$ and skeletal muscle (29) than is palmityl carnitine suggested that mitochondrial palmityl CoA synthetase and/or formation of palmityl carnitine might be rate limiting. The results of the present study in which muscle mitochondria oxidized palmitate and palmityl carnitine at approximately the same rate when incubated in the presence of optimal levels of substrate and cofactors, show that this is not the case. The very low rates of palmitate oxidation by muscle mitochondria noted in the previous studies were probably due to the absence of CoA from the incubation media $(28,29)$. As reported by Fritz and Yue for heart mitochondria (21) and demonstrated in the present study with skeletal muscle mitochondria,

TABLE IV

ATP-Dependent Palmityl CoA Synthetase, Carnitine Palmityltransferase, and Palmityl CoA Dehydrogenase Activities in Hind Limb Muscles of Exercised and Sedentary Rats

\begin{tabular}{lccc}
\hline & $\begin{array}{c}\text { ATP- } \\
\text { dependent } \\
\text { palmityl CoA } \\
\text { synthetase }\end{array}$ & $\begin{array}{c}\text { Carnitine } \\
\text { palmityltransferase }\end{array}$ & $\begin{array}{c}\text { Palmityl CoA } \\
\text { dehydrogenase }\end{array}$ \\
\hline Runners & $75 \pm 6^{*}(9)$ & nmoles $/$ min per $g$ & \\
Sedentary & $33 \pm 1(9)$ & $132 \pm 8^{*}(6)$ & $970 \pm 106^{*}(6)$ \\
\hline
\end{tabular}

Values are means 土SEM. Number of animals in each group is given in parentheses. Enzymatic activity is expressed as nanomoles of substrate utilized per minute by the mitochondrial fraction from $1 \mathrm{~g}$ of muscle, we? weight.

* Runners vs. sedentary, $P<0.001$. 
both CoA and carnitine are necessary cofactors for the oxidation of long-chain fatty acids by intact muscle mitochondria.

It was previously found that the program of exercise used in these studies results in an approximately twofold increase in the levels of activity of the mitochondrial respiratory chain enzymes linking the oxidation of NADH and succinate to oxygen (9). This rise in enzyme activity appears to be due to an increase in enzyme protein, as evidenced by a doubling of the concentration of cytochrome c, and a $60 \%$ increase in the protein content of the mitochondrial fraction of skeletal muscle $(9,10)$. A study by Gollnick and King (11) has provided electron microscopic evidence that the adaptation to exercise involves an increase in both the size and number of muscle mitochondria. However, although mitochondria are the site of fatty acid oxidation, it could not be assumed a priori that adaptation to exercise results in an increase in the capacity of muscle to oxidize fatty acids, because muscle mitochondria do not increase as a unit but undergo adaptive changes in composition.

For example, the capacity of muscle to oxidize $\alpha$ glycerophosphate is not increased in physically trained rats (10). Mitochondrial $\alpha$-glycerophosphate dehydrogenase, although also a component of the mitochondrial cristae, does not participate in the adaptive increase in the constituents of the respiratory chain that occurs in response to exercise (10). Thus, because of the increase in mitochondrial protein, $\alpha$-glycerophosphate dehydrogenase activity is significantly decreased in leg muscles of physically trained rats when expressed per milligram of mitochondrial protein (10). Similarly, mitochondrial adenylate kinase and creatine kinase do not participate in the adaption to exercise and show a significant decrease in specific activity per milligram of mitochondrial protein..$^{2}$ The finding in the present study that exercise significantly increased the capacity to oxidize palmitate not only per gram of muscle but also per milligram of mitochondrial protein provides further evidence of a change in mitochondrial composition.

It was previously found that the levels of activity of citrate synthase and NAD-specific isocitrate dehydrogenase and of the respiratory chain enzymes increased to the same extent, approximately twofold, in leg muscles of rats subjected to the exercise program used in these studies (12). In contrast, the level of activity of the citric acid cycle-related enzyme, glutamate dehydrogenase, increased by only one-third (12). Pette and his coworkers $(30,31)$ have shown that certain mitochondrial citric acid cycle and citric acid cycle-related en-

\footnotetext{
${ }^{1}$ Oscai, L. B., and J. O. Holloszy. Manuscript in prepara-
} tion. zymes occur in constant proportions to each other and to the flavoproteins and cytochromes of the respiratory chain. Viewed in this context, the present finding that the levels of mitochondrial palmityl CoA synthetase, carnitine palmityl transferase, and palmityl CoA dehydrogenase all increased to about the same extent as did the concentration of cytochrome c (approximately twofold), raises the possibility that these enzymes of fatty acid catabolism may also be "constant proportion" enzymes which are regulated in a coordinated, quantitatively related manner with the respiratory chain enzymes.

The rate of oxidation of free fatty acids by muscle increases with plasma concentration in resting and exercising animals $(32,33)$. A similar effect of fatty acid concentration was seen in vitro in the present study in which the rate of palmitate oxidation by the mitochondrial fraction (and whole homogenate) of leg muscles from both the exercised and sedentary animals increased with palmitate concentration in the range from 0.125 to $0.75 \mathrm{~mm}$. However, at all concentrations studied, the rate of palmitate oxidation was approximately twice as great in the muscle preparations from the trained as from the sedentary animals.

Physically trained individuals derive a much greater percentage of their energy from fatty acid oxidation than do untrained during exercise of the same intensity $(1,6-8)$. The present results, showing that regularly performed endurance exercise results in an adaptive increase in the capacity of muscle to oxidize fatty acids, helps to explain this difference. In addition to its effect on muscle, exercise appears to produce adaptations, which result in a greater rate of release of fatty acids from adipose tissue and higher levels of free fatty acids in blood, in trained than in untrained subjects during exercise $(5,34)$. It seems likely that the increase in the capacity of muscle to oxidize fat and the greater mobilization of fatty acids act synergistically to account for the physically trained individual's greater utilization of fat as an energy source during exercise.

Men and animals that have adapted to regularly performed endurance exercise, such as long-distance running, demonstrate a marked increase in their capacity to perform aerobic work $(9,35-37)$. One manifestation of this adaptation is an increase in endurance, measured as an increase in the period of time for which an individual can maintain a given submaximal level of exercise $(9,14,38)$. The shift in the carbon source for the citric acid cycle in skeletal muscle that occurs in response to physical training with increased oxidation of fat and a reduction in carbohydrate utilization (1, 6-8), may play an important role in this increase in endurance.

One factor which has been implicated in the develop- 
ment of the muscle fatigue, which forces an exercising individual performing prolonged exercise to stop or markedly slow his pace, is a depletion of muscle glycogen $(39,40)$. Why glycogen depletion should have this effect, when large amounts of substrate in the form of fatty acids are still available, remains to be clarified; nevertheless, the fatigue and reduction in work capacity associated with glycogen depletion are well documented $(39,40)$. Clearly, the glycogen-sparing effect of increased utilization of fat could postpone depletion of muscle glycogen and the fatigue associated with it in the exercising muscle of physically trained individuals.

Another factor which may limit endurance in individuals performing heavy work of several hours duration is hypoglycemia with associated central nervous system symptoms $(41,42)$. An increase in the oxidation of fatty acids decreases carbohydrate utilization (43). This appears to be mediated, in part, by decreased uptake of glucose by muscle (44). A greater oxidation of fatty acids by skeletal muscle could, through this mechanism, protect physically trained individuals against the development of hypoglycemia during prolonged exercise.

\section{ACKNOWLEDGMENTS}

We wish to express our appreciation to Mrs. May Chen for skillful technical assistance, and to Mrs. Lenore Alberty for help in preparation of this manuscript.

This work was supported by U. S. Public Health Service Research Grant HD01613 from the National Institutes of Health.

\section{REFERENCES}

1. Christensen, E. H., and O. Hansen. 1939. Arbeitsfähigkeit und ehrnährung. Skand. Arch. Physiol. 81: 160.

2. Havel, R. J., A. Naimark, and C. F. Borchgrevink. 1963. Turnover rate and oxidation of free fatty acids of blood plasma in man during exercise: studies during continuous infusion of palmitate-1- $\mathrm{C}^{14} . \mathrm{J}$. Clin. Invest. 42: 1054 .

3. Paul, P., and B. Issekutz. 1967. Role of extramuscular energy sources in the metabolism of the exercising dog. J. Appl. Physiol. 22 : 615.

4. Zierler, K. L., A. Maseri, G. Klassen, D. Rabinowitz, and J. Burgess. 1968. Muscle metabolism during exercise in man. Trans. Ass. Amer. Physicians Philadelphia. 81: 266.

5. Havel, R. J., L. A. Carlson, L.-G. Ekelund, and A. Holmgren. 1964. Turnover rate and oxidation of different free fatty acids in man during exercise. J. Appl. Physiol. 19: 613.

6. Asstrand, P.-O. 1967. Diet and athletic performance. Fed. Proc. 26: 1772.

7. Saltin, B., and J. Karlsson. 19i1. Muscle glycogen utilization during work of different intensities. In Muscle Metabolism during Exercise. B. Pernow and B. Saltin, editors. Plenum Press, New York. 289.
8. Issekutz, B., Jr., H. I. Miller, and K. Rodahl. 1966 Lipid and carbohydrate metabolism during exercise. Fed. Proc. 25 : 1415.

9. Holloszy, J. O. 1967. Biochemical adaptations in muscle. Effects of exercise on mitochondrial oxygen uptake and respiratory enzyme activity in skeletal muscle. $J$. Biol. Chem. 242: 2278.

10. Holloszy, J. O., and L. B. Oscai. 1969. Effect of exercise on $\alpha$-glycerophosphate dehydrogenase activity in skeletal muscle. Arch. Biochem. Biophys. 130: 653.

11. Gollnick, P. D., and D. W. King. 1969. Effect of exercise and training on mitochondria of rat skeletal muscle. Amer. J. Physiol. 216: 1502.

12. Holloszy, J. O., L. B. Oscai, I. J. Don, and P. A. Molé. 1970. Mitochondrial citric acid cycle and related enzymes: adaptive response to exercise. Biochom. Biophys. Res. Commun. 40: 1368.

13. Molé, P. A., and J. O. Holloszy. 19;0. Exercise-induced increase in the capacity of skeletal muscle to oxidize palmitate. Proc. Soc. Exp. Biol. Med. 134: 789.

14. Pattengale, P. K., and J. O. Holloszy. 1967. Augmentation of skeletal muscle myoglobin by a program of treadmill running. Amer. J. Physiol. 213: 783.

15. Goodman, D. S. 1957. Preparation of human serum albumin free of long-chain fatty acids. Science (Washington). 125: 1296.

16. Low, B. W. 1952. Preparation and properties of serum and plasma proteins. 34. An X-ray study of crystalline human serum albumin preparations. J. Amer. Chem. Soc. 74: 4830.

17. Van den Bergh, S. G. 1967. Fatty acid activation and oxidation by mitochondria. Methods Enzymol. 10: 749.

18. Jones, J. A., and M. Blecher. 1965. On the mechanism of $\beta$-oxidation of long chain fatty acids by liver mitochondria from normal and alloxan-diabetic rats. J. Biol. Chem. 240: 68 .

19. Pande, S. V., and J. F. Mead. 1963. Long chain fatty acid activation in subcellular preparations from rat liver. J. Biol. Chem. 243: 352.

20. Kornberg, A., and W. E. Pricer, Jr. 1953. Enzymatic synthesis of the coenzyme A derivatives of long chain fatty acids. J. Biol. Chem. 204: 329.

21. Fritz, I. B., and K. T. N. Yue. 1963. Long-chain carnitine acyltransferase and the role of acylcarnitine derivatives in the catalytic increase of fatty acid oxidation induced by carnitine. J. Lipid Res. 4: 279.

22. Bremer, J., and K. R. Norum. 1967. The mechanism of substrate inhibition of palmityl coenzyme A: carnitine palmityltransferase by palmityl coenzyme A. J. Biol. Chem. 242: 1744.

23. Hill, U. T. 1947. Colorimetric determination of fatty acids and esters. Anal. Chem. 19: 932.

24. Hoskins, D. D. 1969. Butyryl-CoA dehydrogenase from monkey liver. Methods Enzymol. 14: 110.

25. Williams, J. N., and S. L. Thorp. 1969. Re-evaluation of cytochrome c concentrations in rat organs using a new method for cytochrome c. Biochim. Biophys. Acta. 189: 25.

26. Gornall, A. G., C. J. Bardawill, and M. M. David. 1949. Determination of serum proteins by means of the biuret reaction. J. Biol. Chem. 177: 751.

27. Cleland, K. W., and E. C. Slater. 1953. Respiratory granules of heart muscle. Biochcm. J. 53: 547.

28. Bremer, J. 1962. Carnitine in intermediary metabolism. The metabolism of fatty acid esters of carnitine by mitochondria. J. Biol. Chem. 237: 3628. 
29. Bode, C., and M. Klingenberg. 1964. Carnitine and fatty acid oxidation in mitochondria of various organs. Biochim. Biophys. Acta. 84: 93.

30. Pette, D., M. Klingenberg, and T. Bücher. 1962. Comparable and specific proportions in the mitochondrial enzyme activity pattern. Biochem. Biophys. Res. Commun. 7: 425 .

31. Pette, D. 1966. Mitochondrial enzyme activities. In Symposium on the Regulation of Metabolic Processes in Mitochondria, Bari, 1965. Proceedings. J. M. Tager, S. Papa, E. Quagliariello, and E. C. Slater, editors. American Elsevier Publishing Co., Inc., New York. 28.

32. Armstrong, D. T., R. Steele, N. Altszuler, A. Dunn, J. S. Bishop, and R. C. de Bodo. 1961. Regulation of plasma free fatty acid turnover. Amer. J. Physiol. 201: 9.

33. Issekutz, B., Jr., H. I. Miller, P. Paul, and K. Rodahl. 1964. Source of fat oxidation in exercising dogs. Amer. J. Physiol. 207 : 583.

34. Issekutz, B., Jr., H. I. Miller, P. Paul, and K. Rodahl. 1965. Aerobic work capacity and plasma FFA turnover. J. Appl. Physiol. 20: 293.

35. Robinson, S., H. T. Edwards, and D. B. Dill. 1937. New records in human power. Science (Washington). 85: 409.

36. Robinson, S., and P. M. Harmon. 1941. The lactic acid mechanism and certain properties of the blood in relation to training. Amer. J. Physiol. 132: 757.
37. Saltin, B., G. Blomqvist, J. H. Mitchell, R. L. Johnson, K. Wildenthal, and C. B. Chapman. 1968. Response to exercise after bed rest and after training. Circulation. 38(Suppl. 7) : vii.

38. Karpovich, P. V., and K. Pestrecov. 1941. Effect of gelatin upon muscular work in man. Amer. J. Phy'siol. $134: 300$.

39. Ahlborg, B., J. Bergström, L.-G. Ekelund, and E. Hultman. 1967. Muscle glycogen and muscle electrolytes during prolonged physical exercise. Acta Physiol. Scand. 70: 129 .

40. Bergström, J., L. Hermansen, E. Hultman, and B. Saltin. 1967. Diet, muscle glycogen and physical performance. Acta Physiol. Scand. 71: 140.

41. Christensen, E. H., and O. Hansen. 1939. Hypoglykämie, arbeitsfähigkeit, und ermüdung. Skand. Arch. Physiol. 81: 172.

42. Pruett, E. D. R. 1970. Glucose and insulin during prolonged work stress in men living on different diets. J. Appl. Physiol. 28: 199.

43. Paul, P., B. Issekutz, Jr., and H. I. Miller. 1966. Interrelationship of free fatty acids and glucose metabolism in the dog. Amer. J. Physiol. 211: 1313.

44. Randle, P. J., E. A. Newsholme, and P. B. Garland. 1964. Regulation of glucose uptake by muscle, 8. Effects of fatty acids, ketone bodies and pyruvate, and of alloxan-diabetes and starvation, on the uptake and metabolic fate of glucose in rat heart and diaphragm muscles. Biochem. J. 93: 652 . 